\begin{tabular}{c} 
INDIKATORS Vol 1 (2) (2019) \\
INDIKATORS \\
Journal of Economics and Business \\
http://indicators.iseisemarang.or.id/index.php/jebis \\
\hline
\end{tabular}

\title{
Dividend Determinants of Indonesian Sharia Stocks List (Case Study for The Period of 2009-2017
}

Farikha Amilahaq ${ }^{凶}$

Universitas Islam Sultan Agung

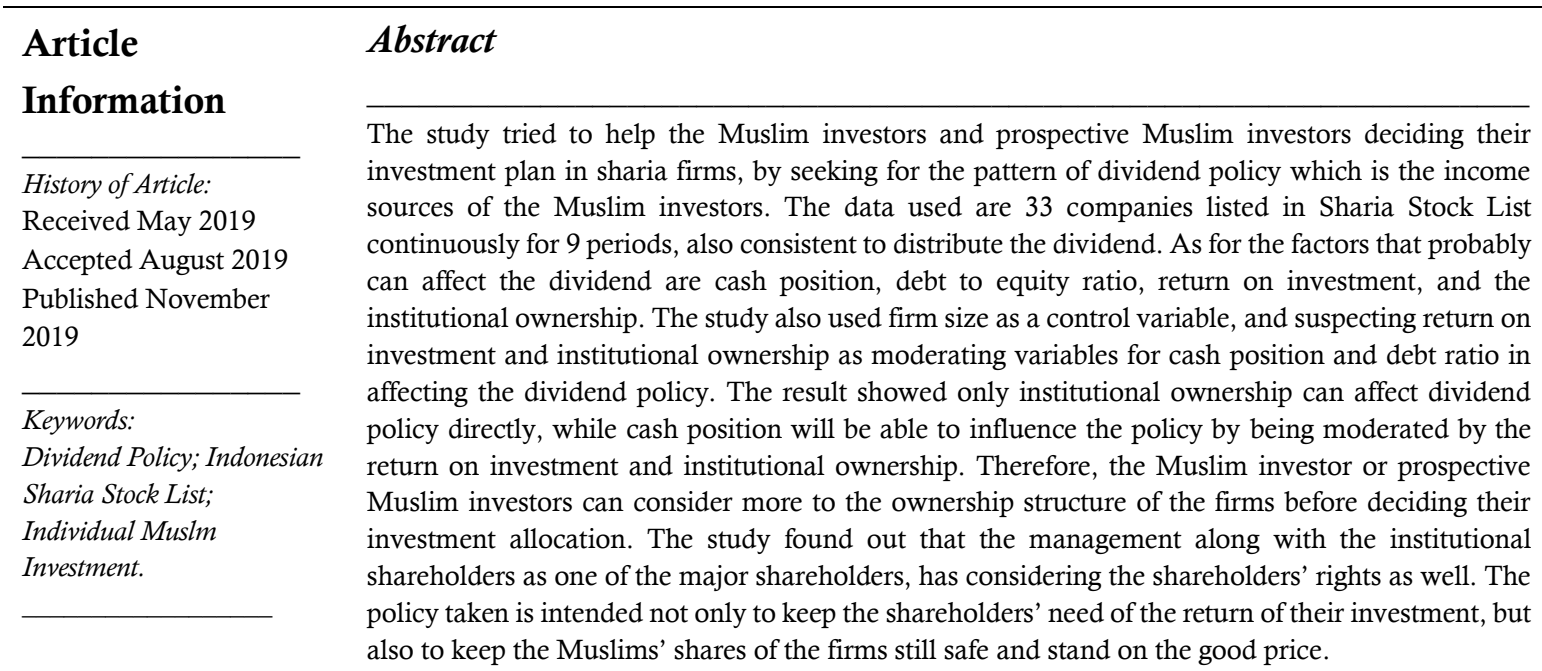

\footnotetext{
${ }^{\square}$ Correspondence Author:

J1. Kaligawe Raya No.KM. 4, Terboyo Kulon, Kec. Genuk, Kota

Semarang, Jawa Tengah 50112

E-mail: farikha@unissula.ac.id
} 


\section{INTRODUCTION}

Indonesia is Muslim majored population country. Therefore, the Indonesian capital market was developed to accommodate the involvement of Muslim so they can directly and actively be the doer of the capital market. The development is by evolving an Islamic capital market (Rivai, Firmansyah, Veithzal, \& Rizqullah, 2010).

In the Islamic capital market, practically the investors invest in aim to have direct participation in the business, hence commonly the investment is for long term (Rivai et al., 2010). The Muslim investors as shareholders of the sharia firms hope to get a return in a high dividend or a stable dividend year by year so their prosperity of passive income will increase (Ritha \& Koestiyanto, 2013). While the income from a capital gain of fast trading (short selling) is not proper for Muslim investors because it means made the stock as commodities which are inappropriate with Islamic principle. Therefore, predicting dividend that will be paid by the firms is very important to Muslim investors so the investors will be easier to decide their investment plan, at once will attract other prospective Muslim investors. However, the movements of dividend shared year to year was unstable that distress the investors or prospective investors to predict what they will get from the corporation. The fluctuating dividend of sharia stock list can be seen in Figure 1.

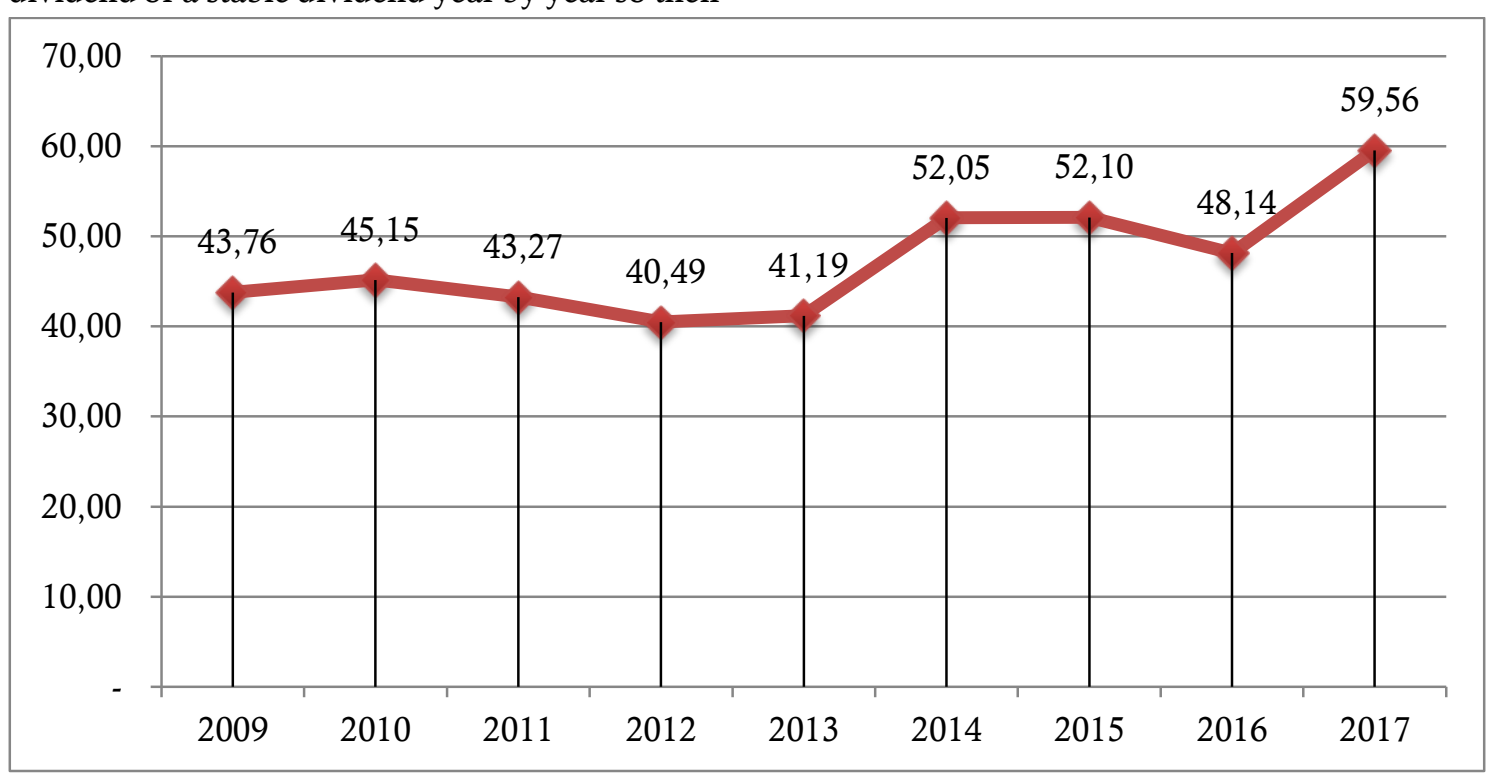

Figure 1. Average Dividend Payout Ratio of The Firms in Sharia Stock List in The Period of 2009 to 2017

Source: Summary of Firms' Annual Report, https://www.idx.co.id, have been processed.

The dividend policy can be influenced by many factors, one of it is the firm's liquidity ratio. Dividend paid to the shareholder is based on the cash flow the firms owned. When the cash position is limited then it will be hard for the firms to distribute the dividend out of the firms' to the shareholders' personal account. Thus can be said that the better firm's liquidity means the bigger of the firm's capability to pay the dividend (Christi \& Wijayanti, 2013; Pribadi \& Sampurno, 2012; Riyanto, 2008; Tarigan, 2008). However, there is a possibility that the firms pay the dividend regularly or constantly as their duty towards the shareholder, no matter what condition of the cash position (Afza, 2010; Hadiwijaya \& Triani, 2009; Kadir, 2010; Musiega, Alala, Douglas, Christopher, \& Robert, 2013; Pasaribu, 2014).

Nevertheless, (Hadiwijaya \& Triani, 2009; Kadir, 2010; Musiega et al., 2013; Pasaribu, 2014; Tarigan, 2008) agreed that the dividend will be paid due to the profits achieved, thus the 
higher profits achieved will increase the probability to distribute the higher dividend as well.

Empirical findings belong to (Gill, Biger, \& Tibrewala, 2010; Rehman \& Takumi, 2012) showed that the capital structure of firms dominated by debt (liability) will force the management prior paying the liability than giving dividend. So the dividend amount will decrease or even they will not pay the dividend because of leverage (Amah, 2012; Devi \& Erawati, 2014; Gill et al., 2010; Kadir, 2010; Pasaribu, 2014; Rehman \& Takumi, 2012).

In another side, (Arifin, 2007) stated that the shareholding dominated by institutional ownership can be a good sign for dividend payment. This is because the bigger institutional ownership means the bigger control system by them (policy control), then they have huge power to speak up the dividend execution. Thus the researches finding of (Embara, Wiagustini, \& Badjra, 2012; Sanjaya, 2009) have shown the same meaning.

The fluctuation of dividends and the different findings of previous researches about dividend's determinants made it is good to find out the greatest factors that be able to influence the dividend of sharia firms. Moreover, the study of sharia firms' dividend in Indonesia is still less. This research is also can assist Muslim investors and prospective Muslim investors to put their interest in investment toward sharia firms.

Base on the important of dividend for Muslims investors, the fluctuation dividend which is do not suit with the investors' expectation (phenomenon gap), the different findings about the determinants of dividend (research gap), and the less research about dividend in sharia firms, arise the problem statement of how the significant impact of fundamental ratios of the firms toward dividend. These fundamental ratios that will be analyzed are cash position, return on investment, debt to equity ratio, and institutional ownership. While the aims of this research are (1) to prove empirically that the cash position, return on investment, debt to equity ratio, and institutional ownership have the significant impact toward dividend payment, and (2) figure out about the characteristics of dividend in sharia firms.

Due to the previous research that giving different result, then in this study try to involving the size of the firms as a control variable so that the result is expected more precise (Ajanthan, 2013; Gill et al., 2010; Sumartha, 2016), and moderate the cash position towards dividend by the profitability of the firm as the solution of the research gap mentioned before.

Indonesia as one of the Muslim majored population countries is a huge market for Islamic financial industries development. Sharia investment in stock exchange which is the part of the Islamic financial industry has an important role in increasing the market share of Islamic financial industry in Indonesia. Along with the significant progress of the stock exchange industry in Indonesia, then it is expected that sharia investment will also have a rapid growth (Indonesia Stock Exchange, 2015b).

Islam regulates all human's daily activities by Al Qur'an and al Al Hadits, it is including economic activity such as investment. Investment is an activity that is highly encouraged by Islam because by investing, the Muslims' wealth will be more productive and can provide an advantage for others (Rivai et al., 2010, p. 555). It is written in Al Qur'an Surah. Al Tawbah [9]: 105 and Q.S. Ali Imran [3]: 145. Moreover, if the investment is done in order to get blessed from Allah SWT, then they can get the happiness in the world and the hereafter at once (Nafik, 2009).

Investing shares in capital stock is analogous of what called as syirkah (partnership) in Islamic Economic, and the investors who invest in shares for dividends as the returns aimed is allowed (Hulwati, 2001). The return received is proportional based on the investment of each investor have put in, and based on the joint policy that usually will be discussed together in the General Meeting of Shareholders.

In developing Indonesia sharia capital market, National Sharia Council-Indonesian Religious Leader (DSN-MUI) formulated many rules to organize the application of transaction in the finance industry. These rules are called fatwa. 
The fatwa that contains Capital Market and the General Guidelines of Sharia Principles Implementation in Capital Market Sector (Fatwa no. 40/DSN-MUI/X/2003) is based on $\mathrm{Al}$ Quran, Al Hadits, and the rules of jurisprudence (fiqih). Then, in 2007 Control Board of Capital Market and Financial Industry (BAPEPAM-LK) released Sharia Stock List which consists of sharia firms listed in Indonesia (Indonesia Stock Exchange, 2015a).

A dividend is an allocation of a firm's net profit for the shareholders, that have been approved in the General Meeting of Shareholders (RUPS) (Darmadji \& Fakhruddin, 2012). Dividend payment by the go public firms has a significant impact both for investors and the firms themselves because the dividend is very important to fulfill the shareholders' interest toward the part of the return of the firms (Hermuningsih, 2007). (Halim, 2003) divided the payment dividend become three (3) characteristics, they are as follows:

\section{Dividend in Stable Amount}

Dividends per share paid in each year are relatively constant for certain time periods, although the earning per share in each year is fluctuating. This kind of dividend will encourage the investors' perception that the firms have a good prospect in the future. Therefore, the firm's management can comply with the investors' want by the policy of a stable dividend.

Some firms give the dividend according to the certain percentage of profit. Because of the fluctuated profit, this method will affect the dividend fluctuate too.

This policy gives the flexibility to the firm, but it affects the shareholders' doubt about how many dividends they can get. However, if the profit is so fluctuating, this is the best policy by the firm.

Research about dividend payout ratio has been done many times both in Indonesia or other countries. For example, the research by (Musiega et al., 2013) about the firms in Nairobi Securities Exchange, Kenya. They analyzed dividend payout ratio with the independent variables were current earnings, liquidity, profitability, and growth opportunities, and found out that the significant factors were growth and current earnings. In Indonesia (Pasaribu, 2014) analyzed the dividend payout ratio of Emiten of LQ-45 at Indonesia Stock Exchange. While the independent variables analyzed were cash ratio, ROI, asset turnover, DER, DAR (debt to asset ratio), NPM (net profit margin), and size, and they found that the significant factors of dividend payout ratio were asset turnover, DAR, DER, and ROI. (Pribadi \& Sampurno, 2012) also did research about dividend payout ratio use cash position, firm size, growth opportunity, ownership, and ROA as the independent variables. Then, they found the significant factors were ownership, cash position, firm size, and ROA.

Therefore, in this study will use some of the significant factors due to the previous research, such as the liquidity ratio (cash position), profitability (return on investment), capital structure by debt (debt to equity), and institutional ownership, and use the firm size as the control variable along with the profitability and the institutional ownership also become the moderating for the cash position and debt to equity toward dividend (Ajanthan, 2013; Gill et al., 2010; Sumartha, 2016).

Cash position is one of the firm's liquidity measurement instrument (Pribadi \& Sampurno, 2012). A dividend is a cash outflow. When the management is going to distribute the dividend then they must have enough cash on their balance to be distributed to each shareholders' personal account. So that liquidity rate especially cash position is an important variable which will be considered by management for deciding the dividend policy (Riyanto, 2008). The liquid cash of the firm that means there is the ability to pay the dividend was also proved by (Christi \& Wijayanti, 2013; Pribadi \& Sampurno, 2012; Tarigan, 2008).

Debt to equity ratio (DER) reflects the firm's ability to fulfill the liabilities which is showed by the capacity of the equity in covering the total liabilities (Sumiadji, 2011). Debt policy related to the funding policy of the firm. It means this the debt decision is taken by the firm in order to get the additional capital for the firm to be used 
to fund the business. The usage of debt as funding sources will make the firm must bear the fixed burdens such interest and debt repayment (Pasaribu, 2014). The higher debt ratio used in capital structure means the higher leverage and this will also affect the amount of profit can be distributed toward the shareholder. This is because the leverage is more prioritized than the shareholders' right of dividend (Kadir, 2010).

Even more, in some cases there are requirements that tend to protect the bond or another such debt, it is consist of dividend payment limitation. This limitation means to keep the firm's ability to be able to pay the debt repayment and interest. This kind of requirement will impact the amount of dividend payout ratio (Riyanto, 2008, pp. 267-268). In other words, if the debt is high the possibility of the firm to distribute the dividend will be less. The argument also has been confirmed by (Amah, 2012; Devi \& Erawati, 2014; Gill et al., 2010; Kadir, 2010; Rehman \& Takumi, 2012).

Return on investment is the rate of profit from the utilization of total assets for business (Kadir, 2010). Profitability ratio reflects the firm's accomplishment in obtaining the earnings. The rate return on investment expected will affect the determination to pay the earning in dividend form toward the shareholders (Copeland \& Weston, 1992, pp. 99-101). Therefore, a firm with a stable return is able to assign the rate of dividend confidently and provide a signal of good corporate performance.

This discussion is not only supported by (Copeland \& Weston, 1992; Kadir, 2010) but also supported by (Hadiwijaya \& Triani, 2009; Indonesia Stock Exchange, 2015b; Musiega et al., 2013; Tarigan, 2008).

Moreover, profitability is the main factor that becomes the shareholders' first deliberation in deciding whether to distribute the dividend and how much it is. In another view, the higher earnings perhaps can be means there is higher cash flow, then, can be predicted that the corporation will pay the higher dividend as well. Thus, it means the existence of good earning will can moderate the higher position of cash flows in order to support the dividend distribution (Kadir, 2010).

Debt is related to the funding policy. The management can be adding the fund for their business by having more debt, or retain the profit achieved become retained earning that will be able to run the business more. Therefore the existence of the profit is not only can be allocated as the shareholders' rights but also as the source to replace the debt dependence as capital. It means the profit gotten is not only can strengthen the cash position but also diminish the effect of debt toward dividend policy.

Institutional Ownership is a percentage of the shares belong to the institutional shareholders. Usually, institutional ownership is the corporations which invest their money on the other corporation, i.e. insurance corporation, main company, relations company, state-owned enterprises, etc. The percentage can be counted by the amount of investment compared with the total asset of the firm.

The big ownership of share by institutional will be able to intervene in the management in taking the policy, especially if it is about earnings allocations. Then, the firm can decide to allocate the earning in a stable percentage of dividend (Pribadi \& Sampurno, 2012). This is because the high institutional ownership ratio can diminish the agency conflict that usually is caused by the different interest between the management and the shareholders. The institutional shareholder is also considered competent to monitor toward the internal corporate performance, in order for having the optimal return of the business, and the end will affect to the earning allocation for dividend payment (Ritha \& Koestiyanto, 2013). So that the institutional ownership's presence has a substantial effect on the dividend payment and to reduce agency cost (Sanjaya, 2009). This is also supported by (Afza, 2010; Copeland \& Weston, 1992; Embara et al., 2012; Pribadi \& Sampurno, 2012).

The agency conflict usually is triggered by the over of cash flows position that made people judge the management had been unable to manage the asset effectively. 
Therefore the excess cash is ought to distribute as a dividend only if the institutional shareholders have got through the corporation and prevent the management create the earning management in order to minimize the existence of the cash.

For shareholders, maintaining the debt will weaken the control from the shareholders toward corporate management. Therefore the shareholders' tendency may be for reducing the role of the debt for the company, that means the corporate is supposed to fulfill the investment requirement of the firms by using the retained earnings, while shareholders must sacrifice their dividend portion (Riyanto, 2008, pp. 267-268)
In another word, the existence of institutional ownership is also can tend to affect how the excess cash (over cash position) will be used; it is for adding the dividend payment, or reduce the dividend in order support the management to diminish the dependence of the firm on debt. The institutional ownership can moderate them, strengthen or weaken.

Based on literature reviews and previous researches, so need to be done the research according to the factors affect dividend payout ratio to the firms which fulfill the condition of Islamic principles firms, in Indonesia. While the theoretical framework has built as showed in Figure 2.

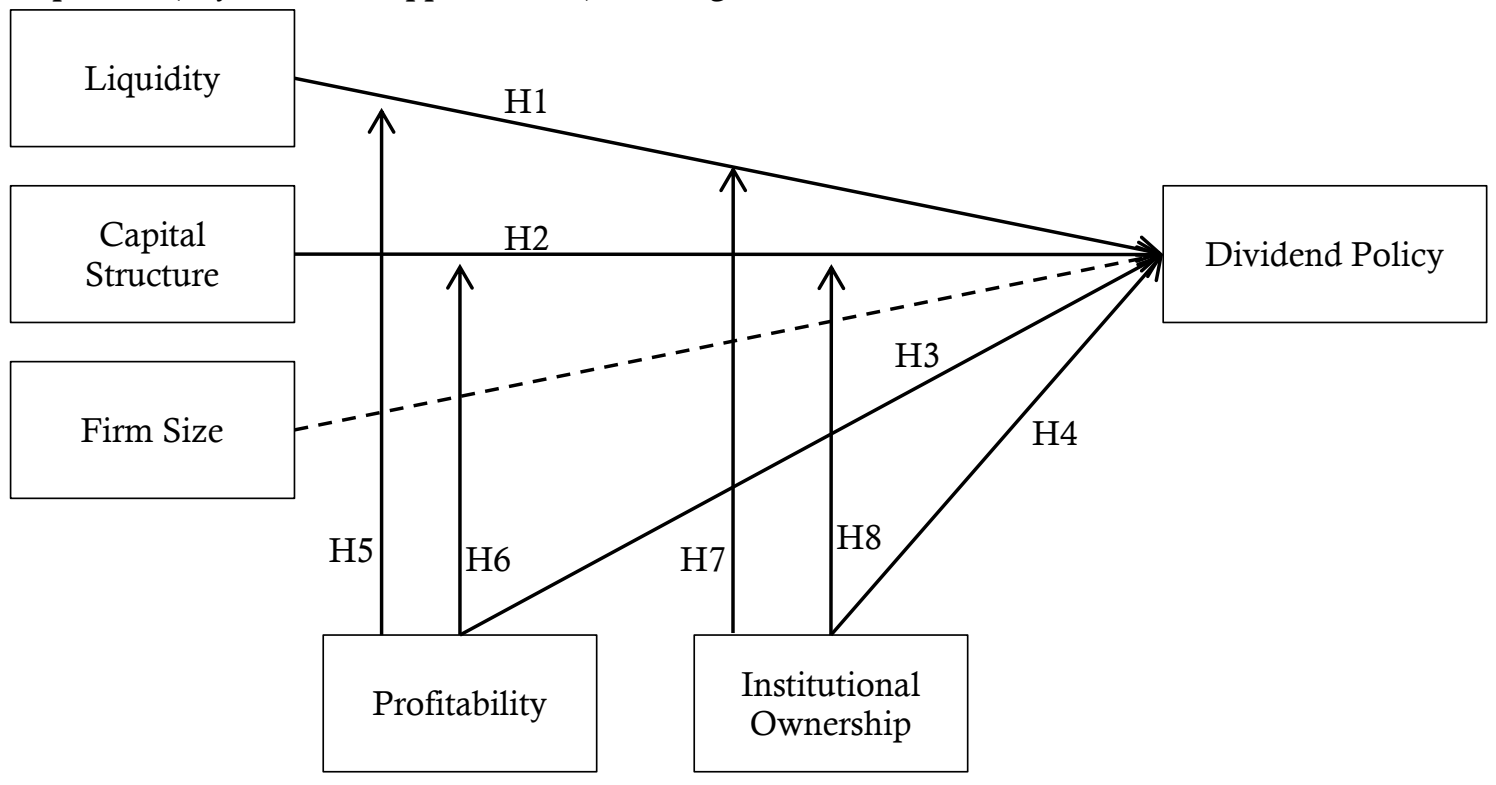

Figure 2. Research Model of Dividend Payout Ratio

Source: (Afza, 2010; Ajanthan, 2013; Amah, 2012; Christi \& Wijayanti, 2013; Devi \& Erawati, 2014; Embara et al., 2012; Gill et al., 2010; Hadiwijaya \& Triani, 2009; Jain \& Chu, 2014; Kadir, 2010; Musiega et al., 2013; Pribadi \& Sampurno, 2012; Rehman \& Takumi, 2012; Riyanto, 2008; Sanjaya, 2009; Sumartha, 2016; Tarigan, 2008).

\section{RESEARCH METHODS}

The population of this research is all firms in Sharia Stock List since the list was published first in 2009, until 2017. The sample must be the corporation which consistently being listed in the Sharia Stock List in all periods, distributed dividend in all periods, and released their audited annual report. Then only about 33 firms that can be used in this study, at least there will be 297 data.

The data is secondary data got the website of Indonesia Stock Exchange in the form of; the summary of annual financial statements, annual reports, and the financial report of firms, for the period of 2009 to 2017. Based on the aspect of time, data used is called as pooled data, it is combination data between time series data 
and cross-section data. The data is cross-section data that repeatedly observed, within the same time (Yuwono, 2005). So can be said that the data is panel/pooled. Then the regression for pooled data is called Panel Data Regression.

\section{Measurements of Variables}

The formula of each ratios in this research are as follows:

Table 1. Formula/Measurements of Variables

\begin{tabular}{|c|c|c|}
\hline No. & Variables & $\begin{array}{l}\text { Indicator/ } \\
\text { Measurement }\end{array}$ \\
\hline 1. & $\begin{array}{l}\text { Dividend Policy is proxied with Dividend Payout Ratio } \\
\text { (DPR) }\end{array}$ & DPR $=\frac{\text { Dividend Per Share }}{\text { Earning Per Share }}$ \\
\hline 2. & Liquidity is proxied with Cash Position (CP) & $\mathrm{CP}=\frac{\text { Year End Cash }}{\text { Eat After Tax }}$ \\
\hline 3. & Profitability is proxied Return on Invesment (ROI) & $\mathrm{ROI}=\frac{\text { Earning After Tax }}{\text { Total Asset }}$ \\
\hline 4. & $\begin{array}{l}\text { Capital Structure is proxied with Debt to Equity Ratio } \\
\text { (DER) }\end{array}$ & $\mathrm{DER}=\frac{\text { Total Liability }}{\text { Total Equity }}$ \\
\hline 5. & Institutional Ownership (IO) & IO $=\frac{\text { Share belong to Ins. }}{\text { Total Shares }}$ \\
\hline 6. & Firm Size & Ln Size \\
\hline
\end{tabular}

Source: Processed from sources variety.

\section{RESULT AND DISCUSSION}

Sample for this study is 33 firms that listed as sharia stocks countinously since 2009 until 2017.
Then the total data is 297. The data can be resumed in descriptive statistic as below.

Table 2. Descriptive Statistic

\begin{tabular}{lllllll}
\hline & DPR & CP & DER & ROI & IO & SIZE \\
\hline Mean & 49.33 & 201.10 & 80.03 & 13.40 & 70.86 & $56,671,344,340,067.3$ \\
\hline Median & 38.46 & 152.93 & 63.59 & 11.05 & 68.08 & $4,202,515,000,000$ \\
\hline Maximum & 794.12 & 2074.69 & 290.30 & 53.17 & 99.36 & $1578,474,000,000,000$ \\
\hline Minimum & 1.85 & 4.75 & 6.41 & 0.44 & 32.22 & $7,283,100,0000$ \\
\hline Std. Dev. & 65.40 & 201.52 & 61.06 & 9.71 & 17.00 & $227,861,562,797,776$ \\
\hline Observations & 297 & 297 & 297 & 297 & 297 & 297 \\
\hline Sourc & & & & &
\end{tabular}

Sources: Author's documentation

Based on the data, can be known generally the average percentage of dividend that had been distributed by the firms that entered in the sharia stock list. The dividend payout ratio distributed by the firms are very varied, from the smallest $(1.85 \%)$ until eight times of the profit gotten on the following period. The variants also appear in other financial ratios such as cash position ratio, debt ratio, profitability, also the total assets of the various firms that not even. These all may be happen because of there can be different treatment of each firms management especially between the different classified sectors of the corporation.

The hypothesis testing is done by a panel regression model with eviews. Based on the fit model testing, the fixed effect model is the suitest model, then will be found out the factors that able 
to affect the dividend policy, also for testing the hypotheses mentioned. As for the result can be served in Table 3.

Table 2. Fized Effect Model Regression Resut and Hypothesis Test Results

\begin{tabular}{llllll}
\hline \multicolumn{1}{r}{ Variable } & Coefficient & Std. Error & t-Statistic & Prob. & Result \\
\hline C & 171.1729 & 50.35935 & 3.399029 & 0.0008 & \\
CP & 0.030799 & 0.021312 & 1.445148 & 0.1496 & H1 is rejected \\
DER & 0.082251 & 0.088331 & 0.931173 & 0.3526 & H2 is rejected \\
ROI & -1.330855 & 0.369812 & -3.598737 & 0.0004 & H3 is rejected \\
IO & 0.718836 & 0.200024 & 3.593743 & 0.0004 & H4 is accepted \\
LN_SIZE & -5.479427 & 1.465639 & -3.738593 & 0.0002 & \\
CP*ROI & 0.004534 & 0.001620 & 2.798815 & 0.0055 & H5 is accepted \\
DER*ROI & 0.001752 & 0.002904 & 0.603199 & 0.5469 & H6 is rejected \\
CP*IO & -0.000739 & 0.000290 & -2.546113 & 0.0115 & H7 is accepted \\
DER*IO & -0.001498 & 0.001310 & -1.143568 & 0.2539 & H8 is rejected \\
& & & & & \\
\hline \multicolumn{7}{c}{} \\
\hline
\end{tabular}

Cross-section fixed (dummy variables)

\begin{tabular}{|c|c|c|c|}
\hline \multicolumn{4}{|c|}{ Weighted Statistics } \\
\hline R-squared & 0.680247 & Mean dependent var & 140.5238 \\
\hline $\begin{array}{l}\text { Adjusted } \quad \text { R- } \\
\text { squared }\end{array}$ & 0.628836 & S.D. dependent var & 103.2458 \\
\hline S.E. of regression & 47.99816 & Sum squared resid & 587474.9 \\
\hline F-statistic & 13.23149 & Durbin-Watson stat & 1.761861 \\
\hline Prob(F-statistic) & 0.000000 & & \\
\hline & \multicolumn{3}{|c|}{ Unweighted Statistics } \\
\hline R-squared & 0.309005 & Mean dependent var & 49.32851 \\
\hline $\begin{array}{l}\text { Sum squared } \\
\text { resid }\end{array}$ & 874843.8 & Durbin-Watson stat & 1.250193 \\
\hline
\end{tabular}

Notes: chow test and hausman test give 1 conclusion of fit model, it is fixed effect model.

As for the classic assumption tests will be focused on heteroskedasticity test and autocorrelation test because the data have had a big amount of sample (Ghozali \& Ratmono, 2013, p. 168). Then the classic assumption tests show that the data is homoskedasticity, however it is suffered autocorrelation so the standard error is needed to be corrected.

Source: Secondary data, has been processed by Eviews 10 . 
Based on output of Fixed Effect Model can be arranged the regression equation as follows:

$\mathrm{DPR}=171.1729+0.0308 * \mathrm{CP}_{i t}+$ $0.0823 * \mathrm{DER}_{i t}-1.3309 * \mathrm{ROI}_{i t}+0.7188 * \mathrm{IO}_{i t}-$ $5.4794^{*} \mathrm{Ln} \_S i z e_{i t}+0.0045^{*}(\mathrm{CP} * \mathrm{ROI})_{i t}+$ $0.0018^{*}(\mathrm{DER} * \mathrm{ROI})_{i t} \quad-\quad 0.0007 *(\mathrm{CP} * \mathrm{IO})_{i t} \quad-$ $0.0015^{*}(\mathrm{DER} * \mathrm{IO})_{i t}+\mu_{i t}$

The formula shows the direct influence of each independent variables and the regression coefficient of independent variables towards dividend payout ratio.

\section{Interpretations of Research Results}

The Impact of Cash Position towards Dividend Policy

Base on the hypothesis testing, cash position has an insignificant impact towards dividend on the firms in Sharia Stock List. The not significant impact of cash position towards dividend payout ratio shows that the firm's decision to share the dividend does not make cash position of the firms as the consideration. This is can happen because of the different characteristics of each firm about the decision to share the dividend. Many firms had fluctuated of cash position, but they kept divide the dividend in a stable amount. This result of the research support the result of researches that had been done by (Afza, 2010; Hadiwijaya \& Triani, 2009; Kadir, 2010; Musiega et al., 2013; Pasaribu, 2014) who claimed that cash position has an insignificant impact towards dividend payout ratio.

The influence direction shows that cash position has a positive influence on dividend policy. It means the higher cash position then the dividend payout ratio will be higher too, although the impact is insignificant. It is suitable with the statement that because the dividend is paid in cash so the bigger cash flow will increase the firm's capability to pay the dividend (Riyanto, 2008).

\section{Cash Position is Moderated by Profit and Institutional Ownership}

Cash position cannot influence the dividend directly toward dividend. However, the existence of good corporate performance provides a good impact on the relation of cash position with the dividend policy. This is consistent with what was conveyed with by (Kadir, 2010) that the existence of the profits can strengthen the cash position which in turn will make the company's policy tend to the distribution of dividend.

On the other hand, the increasing cash position is not good news for the institutional shareholders and tends to appraise it as an excess of cash. Therefore, the shareholders will tend to allocate it not for dividend payment.

Institutional shareholders have a very significant impact on dividend policy. It can be interpreted that the institutional shareholders could have certain reasonable limits regarding the amount of dividend they will approve. The institutional shareholders tend not to demand higher dividends than that. It is probably because of they also concern with the business sustainability of the corporate that absolutely will also need the cash for their runs, and also to keep the stability of the corporate value of the firm they have funded.

\section{The Impact of Debt to Equity Ratio towards Dividend Policy}

Base on the hypothesis testing, debt to equity ratio (DER) has insignificant impact towards dividend policy on the firms in Sharia Stock List. Even though when the profit and institutional ownership tried to moderate it. This phenomenon is againts the previous findings that had proved that the existence of debt will affect the dividend policy, and the thing happen differently for the firms listed in sharia stock list.

Principally, the firms that can be listed in sharia stock list must fulfil some requirements. One of it is the interest-based debt must no more than $45 \%$ than the equity. It means since first, all the sharia firms listed have certain limitation. Then this fact of sharia firms study case makes sense.

This research's result is support the researches' result that had been done by (Deitiana, 2009; Rahayuningtyas, Suhadak, \& Handayani, 2014; Sanjaya, 2009; Sumiadji, 2011; Tarigan, 2008) who claimed that debt to 
equity ratio has insignificant impact towards dividend.

The Impact of Return on Investment towards Dividend Policy

Base on the hypothesis testing, return on investment (ROI) has a significant impact towards dividend policy of the firms in Sharia Stock List. However, the direction of influence is negative so that can be interpreted that the higher of profit then the firm tend to not distribute the dividend for shareholders. This matter can be interpreted that although there is a relation, the hypothesis of the study is rejected because of the different direction of influence that does not fit the hypothesis.

This phenomenon becomes unique especially for the sharia firms which is when the corporation is able to provide more profits then it should be distributed towards the shareholders as well, in the form of the more dividend payment. This is suspected related with the increasing of cash position that will happen when the profits are increased so that the management tend to concern more if there will be an agency conflict because of the excess cash that will be considered by the shareholders as the incapability of management in manage the cash optimally. The management is not only concern about dividend policy as the shareholders' rights but also must contemplate the market response about the dividend policy and the fundamental condition of company finance, the market response can be reflected by the corporate value.

\section{The Impact of Institutional Ownership towards Dividend Policy}

Based on the hypothesis testing, institutional ownership (IO) has a significant impact towards dividend policy on the firms of Sharia Stock Listed. The influence direction shows that institutional ownership has a positive impact towards dividend payout ratio. It means the more institutional ownership will impact the dividend payout ratio become higher. This is suitable with the agency theory of ownership and the dividend policy.
Agency conflict can be caused by the difference of interest between the management and the shareholders. This conflict can be diminished by a controlling system to manage the different interests between manager and shareholders.

The institutional shareholder is competent to monitoring the internal corporate performance, in arising the earnings, so that it can impact the allocation of earnings given for shareholders, the dividend (Ritha \& Koestiyanto, 2013). So that the institutional ownership's presence has a substantial effect on the dividend payment and to reduce agency cost (Sanjaya, 2009). This is also supported by (Afza, 2010; Copeland \& Weston, 1992; Embara et al., 2012; Pribadi \& Sampurno, 2012; Sanjaya, 2009).

\section{CONCLUSION}

Based on the result of testing the hypotheses, can be concluded that only institutional ownership can take effect directly towards dividend policy. While the cash position will be able to affect the dividend policy by being strengthened by the existence of profit. However, the high institutional ownership can weaken the contribution of the cash position influence toward dividend policy. Mathematically, from 4 direct influence hypotheses and 4 moderated influence hypotheses, it is only 1 direct influence hypothesis that can be proved, it is institutional ownership. As for the 2 moderated influence hypotheses that can be proved they are by the profitability (return on investment) and institutional ownership. They are able to moderate the influence of the cash position toward dividend policy.

Cash position is unable to influence the dividend policy, but by the increasing of profit then the relation can be stronger, even though the institutional ownership will moderate the relation to the opposite direction (diminish the dividend). The excess cash caused by the increasing profit will increase the dividend payment, but the existence of institutional shareholders limits the influence by using the excess cash not to pay more the dividend. 
This is consistent with the agency theory which the excess cash can be interpreted as the incapability of management in manage the fund. However, distribute all the excess cash from the profit is not the proper decision according to both the management or the institutional shareholders. In other words, there could be an upper limit of dividend payment established by the management and the shareholders. This limit is intended to not harm all the shareholders' rights, also for the sake of the run of corporate's business.

The study is done to help the Muslim investors and prospective Muslim investors deciding their investment plan in sharia firms. Base on the result of the study, can be said that the management along with the institutional shareholders as one of the major shareholders, has considering the shareholders' rights as well. The policy taken is intended to keep the shareholders' need of the return of their investment, also to keep their invested corporation not to go down because of the lack of fund or cash to keep running the business. In other words, the policy is also to keep the Muslims' shares of the firms still safe and stand on the good price.

Therefore, the Muslim investor or prospective Muslim investors can consider more to the ownership structure of the firms before deciding their investment allocation. The good corporation is the one that the institutional ownership is dominant, because of the high monitoring, surveillance, and controlling.

\section{REFERENCE}

Afza, T. (2010). Ownership and Cash Flows As Determminants of Corporate Dividend Policy in Pakistan. International Business Research, 3(3). https://doi.org/10.5539/ibr.v3n3p210

Ajanthan, A. (2013). The Relationship between Dividend Payout and Firm Profitability: A Study of Listed Hotels and Restaurant Companies in Sri Lanka. International Journal of Scientific and Research Publications, 3(6). Retrieved from www.ijsrp.org

Amah, N. (2012). Faktor-faktor yang mempengaruhi Dividend Policy Perusahaan Go Public di
Indonesia. Assets: Jurnal Akuntansi Dan Pendidikan, $1(1)$ https://doi.org/http://doi.org/10.25273/ja p.v1i1.525

Arifin, Z. (2007). Teori Keuangan dan Pasar Modal. Yogyakarta: Ekonisia.

Christi, I., \& Wijayanti, I. (2013). Faktor-faktor yang Mempengaruhi Kebijakan Dividen SK pada Bank-bank yang Terdaftar di BEI. Jurnal Akuntansi \& Bisnis, 1(1). Retrieved from http://docplayer.info/30339340-Jurnalakuntansi-bisnis-vol-1-no-1-september2013.html

Copeland, T., \& Weston, F. (1992). Managerial Finance Eigth Edition. Jakarta: Penerbit Erlangga.

Darmadji, T., \& Fakhruddin, H. M. (2012). Pasar Modal di Indonesia: Pendekatan Tanya Jawab. Edisi 3. Jakarta: Salemba Empat.

Deitiana, T. (2009). Faktor-faktor yang Mempengaruhi Kebijakan Pembayaran Dividen Kas. Jurnal Bisnis Dan Akuntansi, 11(11), 57-64. Retrieved from http://download.portalgaruda.org/article.p hp? article $=153373 \&$ val $=5455 \&$ title $=$ FAKT OR-FAKTOR YANG MEMPENGARUHI KEBIJAKAN DIVIDEN PERUSAHAAN YANG TERDAFTAR DI BURSA EFEK INDONESIA PADA SEKTOR INDUSTRI BARANG KONSUMSI PERIODE 20082011

Devi, N. P. Y., \& Erawati, N. M. A. (2014). Pengaruh Kepemilikan Manajerial, Leverage, dan Ukuran Perusahaan pada Kebijakan Dividen Perusahaan Manufaktur. E-Jurnal Akuntansi Universitas Udayana, 9(3), 709-716. Retrieved from

https://ojs.unud.ac.id/index.php/Akuntans i/article/view/9490

Embara, C. T. D. L., Wiagustini, N. L. P., \& Badjra, I. B. (2012). Variabel-variabel yang Berpengaruh terhadap Kebijakan Dividen serta Harga Saham pada Perusahaan Manufaktur di Bursa Efek Indonesia. Jurnal Manajemen, Strategi Bisnis, Dan Kewirausahaan, 6(2). Retrieved from http://download.portalgaruda.org/article.p hp? article $=14235 \&$ val $=954$

Ghozali, I., \& Ratmono, D. (2013). Analisis Multivariat dan Ekonometrika, Teori, Konsep, dan Aplikasi dengan Eviews 8. Semarang: Badan Penerbit Universitas Diponegoro. Retrieved from https://scholar.google.co.id/citations?user= 
kbmkIQQAAAAJ\&hl=en\#d=gs_md_cita$\mathrm{d} \& \mathrm{u}=\% 2 \mathrm{~F}$ citations\%3Fview_op\%3Dview_c itation $\% 26 \mathrm{hl} \% 3 \mathrm{Den} \% 26 \mathrm{user} \% 3 \mathrm{DkbmkIQQ}$ AAAAJ\%26citation_for_view\%3DkbmkIQ QAAAAJ\%3ASIv7DqKytYAC\%26tzom\%3 D-420

Gill, A., Biger, N., \& Tibrewala, R. (2010). Determinants of Dividend Payout Ratios: Evidence from United States. The Open Business Journal, 3, 8-14. https://doi.org/10.2174/187491510100301 0008

Hadiwijaya, R. D., \& Triani, L. F. (2009). Pengaruh Profitabilitas terhadap Dividend Payout Ratio pada Perusahaan Manufaktur di Indonesia. Jurnal Organisasi Dan Manajemen, 5(2), 49-54. Retrieved from http://jurnal.ut.ac.id/index.php/JOM/artic le/view/25

Halim, A. (2003). Analisis Investasi. Jakarta: Salemba Empat.

Hermuningsih, S. (2007). Analisis Faktor-faktor yang Mempengaruhi Dividend Payout Ratio pada Perusahaan yang Go Public di Indonesia. Jurnal Ekonomi \& Pendidikan, 4(2).

Hulwati. (2001). Transaksi Saham di Pasar Modal Indonesia, Perspektif Hukum Islam. Yogyakarta: UII Press Jogjakarta.

Indonesia Stock Exchange. (2015a). Constituent Index of Indonesia Sharia Stock Index. Retrieved 16 March 2015, from http://www.idx.co.id/id-

$\mathrm{id} /$ beranda/informasipasar/daftarefek/inde kskonstituen.aspx

Indonesia Stock Exchange. (2015b). Sharia Capital Market. Retrieved 16 March 2015, from http://www.idx.co.id/id-

$\mathrm{id} /$ beranda/produkdanlayanan/pasarsyaria h.aspx

Jain, P., \& Chu, Q. C. (2014). Dividend clienteles: a global investigation. Review of Quantitative Finance and Accounting, 42(3), 509-534. https://doi.org/10.1007/s11156-013-0351-2

Jogiyanto. (2010). Metodologi Penelitian Bisnis: Salah Kaprah dan Pengalaman-pengalaman, Edisi 6. Yogyakarta: BPFE Yogyakarta.

Kadir, A. (2010). Analisis Faktor-faktor yang mempengaruhi Kebijakan Dividen pada Perusahaan Credit Agencies Go public di Bursa Efek Indonesia. Jurnal Manajemen Dan Akuntansi, 11(1).

Musiega, M. G., Alala, D. O. B., Douglas, D. M., Christopher, M. O., \& Robert, D. E. (2013).
Determinants of Dividend Payout Ratio Policy Among Non-Financial Firms on Nairobi Securities Exchange, Kenya. International Journal of Scientific \& Technology Research, 2(10). Retrieved from http://citeseerx.ist.psu.edu/viewdoc/downl oad?doi=10.1.1.638.4808\&rep=rep1\&type $=$ pdf

Nafik, M. H. (2009). Bursa Efek dan Investsi Syariah. Jakarta: Serambi.

Pasaribu, R. B. F. (2014). Determinan Dividend Payout Ratio pada Emiten LQ-45 di Bursa Efek Indonesia. Ekonomi \& Bisnis, 8(1), 1-12.

Pribadi, A. S., \& Sampurno, R. D. (2012). Analisis Pengaruh Cash Position, Firm Size, Growth Opportunity, Ownership, dan Return on Asset terhadap Dividend Payout Ratio. Diponegoro Journal of Management, 1(1).

Rahayuningtyas, S., Suhadak, \& Handayani, S. R. (2014). Pengaruh Rasio-rasio Keuangan terhadap Dividen Payout Ratio (DPR) (Studi pada Perusahaan yang Listing di BEI 20092011). Jurnal Administrasi Bisnis (JAB), 7(2).

Rehman, A., \& Takumi, H. (2012). Determinants of Dividend Payout Ratio: Evidence From Karachi Stock Exchange (KSE). Journal of Contemporary Issues in Business Research, 1(1). Retrieved from http://jcibr.webs.com/Archives/Volume 10012/N 1 Oct/V-1-N-1102012JCIBR002.pdf

Ritha, H., \& Koestiyanto, E. (2013). Faktor-faktor yang Mempengaruhi Dividen Payout Ratio. E-Jurnal Manajemen Dan Bisnis, 1(1). Retrieved from https://repository.perbanas.id/xmlui/bitstr eam/handle/123456789/1376/FAKTORFAKTOR YANG MEMPENGARUHI DIVIDEND PAYOUT RATIO \%28DPR\%29.pdf?sequence $=1$

Rivai, V., Firmansyah, R., Veithzal, A. P., \& Rizqullah. (2010). Islamic Financial Management. Bogor: Penerbit Ghalia Indonesia.

Riyanto, B. (2008). Dasar-dasar Pembelanjaan Perusahaan. Yogyakarta: BPFE Yogyakarta.

Sanjaya, I. P. B. (2009). Analisis Faktor yang mempengaruhi Kebijakan Dividen pada Perusahaan Publik di Indonesia. Kajian Akuntansi, 4(1), 15-24.

Sekaran, U. (2006). Metodologi Penelitian untuk Bisnis, Edisi 4, Jilid 1. Jakarta: Salemba Empat. 
Sumartha, E. (2016). PENGARUH STRUKTUR KEPEMILIKAN TERHADAP KEBIJAKAN DIVIDEN PADA PERUSAHAAN MANUFAKTUR. Jurnal Economia, $\quad 12(2), \quad 167$. https://doi.org/10.21831/economia.v12i2. 11114

Sumiadji. (2011). Analisis Variabel Keuangan yang Mempengaruhi Kebijakan Dividen. Jurnal Dinamika Akuntansi, 3(2).
Tarigan, M. U. (2008). Rasio Profitbilitas (ROI), Likuiditas (CR), dan Utang dalam Memprediksi Tingkat Pengembalian Investasi melalui Kebijakan Dividen. Jurnal Akuntansi, 8(1), 147-164.

Yuwono, P. (2005). Pengantar Ekonometri. Yogyakarta: Penerbit ANDI. 